\title{
What A Financing Scandal In A Canadian City Can Teach Us About Ethical Conduct In Government/Business Relations
}

\author{
A. Scott Carson, (E-mail: scarson@wlu.ca), Wilfrid Laurier University, Canada
}

\begin{abstract}
In the mid-sized City of Waterloo, Ontario, Canada, a lease-and-lease-back transaction was arranged with a private sector financial institution to fund the construction of a public park containing ice-rinks, sports fields, a golf course and walking trails. The terms of the transaction were misrepresented to the City. But this was not discovered for months after the deal was signed. A public inquiry followed. In the process many issues of ethical conduct in municipal governance were brought to light. This paper uses the park financing case as a way of exploring some of the ethical issues that have broad application to business/government relations.
\end{abstract}

\section{Introduction}

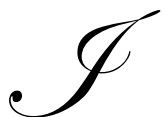

n September 2000, the City of Waterloo, Ontario, Canada entered into a transaction with a leasing company to finance a public park comprised of sports fields, an athletic complex, walking trails and an 18-hole championship golf course. This was a sole-sourced deal. That is, the City had not issued a tender for other bids because it believed that the innovative structure of what was being offered was unique and that the effective rate of interest was below anything it would likely receive elsewhere. The City had been told that it would pay an interest rate of $4.73 \%$ (approximately $2 \%$ below the expected rate if it were to issue debentures - i.e., municipal bonds). And, the required repayments over 31 years would be $\$ 113$ million.

The deal seemed too good to be true. It was! Eight months later, amid wide speculation in the press that the financing was not what it appeared to be, it was discovered that the City Treasurer had never checked the lease payment calculations. The actual rate of interest was $9.2 \%$, and the amount to be repaid was $\$ 228$ million, double what was approved by the City Council.

It was a scandal. There were accusations of fraud, lying and misrepresentation against the leasing company; charges were made that the City councilors and staff were in a conflict of interest position, and that there was a failure by City Council members to exercise reasonable care in their decision making; and it was said that the insurance company that ultimately provided the funding for the lease was guilty of poor corporate citizenship. A renegotiation of the terms of the deal in an out-of-court settlement resulted. The City Treasurer was fired. There was a protracted and very controversial negotiated departure of the City's Chief Administrative Officer (or CAO). And, a long and bitter public inquiry was held as provided for under the Province of Ontario's Municipal Act. The report of the Inquiry, which was released in October 2003, was a damning indictment of administrative incompetence and ethical misconduct. In the municipal elections that followed a month later in November 2003, not one of the sitting City Councilors was re-elected. The fallout continues today with threatened lawsuits and potential insurance claims under the "errors and omissions" clause of the policy.

The citizens of Waterloo regard this as a very grim chapter in the City's history that after five years is still not complete. But, there are lessons to be learned, many of them pertaining to public sector governance, especially with respect to the ethical conduct required of government officials (both elected and salaried administrative staff) in dealing with the private sector. As well, it raises important questions about good corporate citizenship in 
situations where business people know, or should know, that government staff are on unfamiliar turf and have significant gaps in their understanding of the deal.

In this paper, I will detail the facts of the case and draw from them four ethical issues that can arise when governments deal with business. It is difficult to avoid making some judgments about what should or should not have been done in the RIM case, but my primary intent is to consider the lessons learned for broader application to other business/government relationships.

To be considered is, first, what is an elected government's duty of care when entering into business arrangements with the private sector? Second, when governments procure services from the private sector, must they always tender in order to assure fair value for tax payers and fair access to prospective bidders? Third, when government officials deal with the private sector, do they have more stringent conflict of interest standards to meet by virtue of their accountability to the public? Fourth, when businesses transact with government, do they have a special obligation of good corporate citizenship to ensure that the government officials have done, and are capable of doing, adequate due diligence?

\section{The Facts of the Case}

RIM Park is a pristine 500-acre site in the north part of Waterloo, Ontario, Canada. It contains a multipurpose recreational complex, 4 ice rinks, 2 gyms, 18 sports fields, an 18-hole championship golf course and a system of walking trails. It was built at a cost of $\mathrm{C} \$ 56.7$ million and funded by corporate donations, municipal taxes and a 31-year lease-and-lease-back financing. With respect to the latter financing, the City leased the Park to MFP Financial Ltd. (MFP) who made an up-front lease payment of approximately C $\$ 48$ million. MFP then leased the Park back to the City for a stream of payments over 31 years. In a related transaction, MFP sold its interest to Clarica Life Insurance Company (Clarica) who provided the cash to fund the lease. Clarica subsequently sold part of its interest to Maritime Life Assurance Company (Maritime Life).

In September 1998, the then Waterloo City Treasurer attended a conference presentation by MFP executives that demonstrated the potential for municipal infrastructure financings at exceptionally low interest rates (The Hon. Ronald C. Sills, page 49). Subsequently, in Spring 1999, MFP executives and City staff met several times to discuss the possible financing of two municipal projects in Waterloo, a park and a parking garage, at rates that would be roughly $2 \%$ below the likely borrowing rate if the City were to issue debentures. Various financing structures were considered, but what emerged was purportedly a tax driven approach that would allow a corporate partner that MFP would bring into the deal to defer paying tax on the lease payments it was receiving by applying the depreciation (known as capital cost allowance) on the assets in the Park against that income. Part of the tax savings would be returned to the City in the form of a lower rate of interest. The Treasurer was not clear on how this tax structure actually worked. But, he trusted the MFP executive with whom he was directly working.

The parking garage project did not proceed, but RIM Park did. City officials found the potential for low cost funding so attractive that it encouraged them to expand the project scope resulting in a cost escalation from $\mathrm{C} \$ 20$ million to $\mathrm{C} \$ 56$ million. Finally, a year later, in May 2000, the MFP executive handling the Waterloo transaction sent a letter confirming the rate (though at the Inquiry, the President of MFP said that the letter was out of date and was not an authorized offer letter). He also turned up the heat on the City's decision making process by saying that the "good rate" would only be available for a few more months.

It should be noted here that the City's procurement procedures stipulate that major purchases and services need to be tendered - that is, put out to the market for bids. This was not done because the CAO did not think that financing fell under the City's procurement regulations. Also, he was convinced that financing at such a favorable rate would not be available elsewhere and, that should the City go to tender, MFP would withdraw its offer. Further, throughout the period that preceded the signing of the lease, City administrators and elected officials (including, in one case, the Mayor) attended receptions, hockey games and other forms of entertainment hospitality. The Chief Administrative Officer of the City developed a friendship with the MFP executive. After the transaction closed, the CAO continued to be entertained by MFP in the form of golf tournaments and, ultimately, a paid golf trip to Florida. 
The City has conflict of interest guidelines that, depending upon the situation, require at least one of (1) disclosure, (2) higher-level approval, or (3) decline of the benefit. The CAO and others did none of these.

Finally, the details of the proposed transaction were at no point set out in the form of a term sheet signed by both the City and MFP. So, the structure of the financing between the parties was contained largely in conversations, substantially between the City Treasurer and the MFP executive, and in one non-binding letter to the City from the MFP executive.

In early September 2000, the City had been informed that the deal must close by month-end, yet the repayment schedules had to that point not been included with any of the drafts of the lease agreements that the City's external legal counsel had been reviewing. Since the final Council meeting for the month was scheduled for September 25, time was getting short. On September 22, the City Treasurer still had not received the schedules and pressed for their immediate delivery. He was told that the MFP staff was still preparing the final numbers and that the schedule would be available soon.

On the day of the Council meeting, September 25, 2000, the City's Lawyer insisted that the Treasurer remove the financing agreement from that evening's Council agenda because the lease payment schedules had not been delivered. Two hours before the Council meeting, the schedules were hand-delivered by the MFP executive. Shortly afterward, the City Treasurer confirmed to the City's Lawyer that he had checked the schedules and that they reflected the City's understanding of the financing costs. At the City Council meeting that evening, there was very little discussion or questioning of the proposed transaction either during or following the Treasurer's presentation. It passed unanimously. The Mayor was thereby authorized to sign the agreements, which she did.

A few days later, Clarica confirmed that it had purchased the entire transaction from MFP. This came as a surprise to the City. It had not given much thought to how MFP itself would get the money for the deal. But, because Clarica's head office was in Waterloo, and it was one of the City's largest employers, it somehow seemed to City officials that the purchase should have been disclosed earlier. In any event, Clarica then sold a portion of the deal to another insurance company, Maritime Life, and the full transaction was complete.

In the early spring 2001, six months after the lease had been signed, the City was in the process of doing its long-range capital budgeting. However, as staff gathered information for the plan, attempts were made to calculate the lease payments. This was not going well because the amounts being computed were much higher than expected. At about the same time, a reporter from The Record newspaper was assigned to do a story on the tax angle of the lease. The paper thought it had uncovered the use by the City of illegal tax loopholes. It published an article to this effect on May 19, 2002 (The Record, May 19, 2001, page A01). In the process of researching the story, it too was attempting to make the lease calculations and coming up with very different amounts than the City had been representing (The Record, June 1, page A01). In the days that followed, several telephone calls and meetings took place between City staff and MFP to verify the calculations. From all of this the City came away comforted that the rate was $4.73 \%$, though MFP steadfastly denied in the subsequent judicial Inquiry that any such assurances were given.

At the same time that discussions were taking place between the City and MFP, Clarica was asking MFP to reassure them that the City truly understood the nature of the transaction. Clarica had been following the news stories during May and knew the information contained in them to be incorrect. Still, they felt torn between their confidentiality obligation to MFP and their discomfort over the adequacy of the City's understanding of the deal. However, at a meeting on May 29, they asked to be shown the presentation that had been given to the City. In that presentation was a slide that set out the lease calculations and the total amount of C $\$ 227$ million. MFP told Clarica that the news stories about ridiculously low interest rates simply reflected the City's "political spin". Clarica left the meeting satisfied, not realizing that the City had never seen that calculation slide in any presentation from MFP.

The City and MFP met again on May 30 and 31. More discussions about the calculation ensued because the City staff still could not reconcile with the MFP numbers. At this point MFP told them that the 31- year lease required different rates to be applied, and that the "blended" rate was $5.45 \%$. This was devastating for the City staff 
members because now they would have to explain why the total cost of borrowing was roughly $\mathrm{C} \$ 12$ million higher than expected. On June 1, City staff met with the Mayor and legal counsel to determine how best to proceed. The decision was to commence litigation and a press release was prepared which tried to explain that the rate was higher than expected, but still very good.

On June 4, The Record published a story in which legal action was referenced (though it had not yet formally commenced). Immediately a red flag went up at Clarica. They phoned the City directly. The City faxed to Clarica a draft of the press release and a letter from MFP outlining the "good rate". It was now very clear to Clarica that the City did not understand the deal. The head of the corporate finance group at Clarica went immediately to the President of Clarica, who, in turn, telephoned the City's Chief Administrative Officer. The purpose of the call was to ask that the City not issue the press release because it was incorrect and would cause embarrassment to the City.

At Clarica's request, a meeting took place in the evening of June 4, 2001 between senior city staff, the city solicitor, MFP executives, Clarica executives and the Mayor of Waterloo. At that meeting, Clarica produced a 14column spreadsheet showing the total lease payments to be $\mathrm{C} \$ 227.7$ million. The city staff had only seen a 12 column version of the document that did not show the lease payments!

Testimony before the Inquiry by the City Treasurer captures the emotion in his reaction: "At that point, the documents were circulated around the table. And that was the first time in - in my life, that I think I could actually hear the blood rushing through my veins.... And, as another city staff member said in his testimony: "I guess you could say, we went into a bit of a state of shock, because it was at that point that we, at last, finally had - had the truth before us. That, instead of paying somewhere in the neighborhood of ... C $\$ 112$ million, we were going to be paying over double that amount...."

As it turned out, there never was a tax angle. The complex structure only resulted in what was essentially a straight loan. MFP pocketed a $\mathrm{C} \$ 11$ million fee. Half that amount would have been excessive according to Clarica (Sills, page 281).

It was not until June 20, 2001 that the citizens of Waterloo learned the true cost of the Park when Clarica confirmed in the local newspaper the actual amounts (The Record, June 20, 2001, page A01). At the end of June, the City announced that it was initiating legal action against MFP (The Record, June 30, 2001, page B01). Subsequently, Clarica and Maritime Life were added to the suite (the Record, July 25, 2001, page A01). The case did not go to trial. In February 2002, an out of court settlement was reached. The overall repayment amount was reduced to $\mathrm{C} \$ 145.2$ million (still $\mathrm{C} \$ 33$ million in excess of the amount approved by Waterloo City Council). And, the effective interest rate was lowered to $\$ 7.4 \%$. This, too, was considerably above the approximate rate of $6.5 \%$ that could have been achieved if the City had simply borrowed the money by way of municipal debentures.

In April 2002, The Honorable Justice Ronald C. Sills of the Ontario Superior Court was appointed under the Province of Ontario's Municipal Act to conduct an inquiry. His report was published 18 months later in October 2003, just in time for the November municipal election, which, as indicated earlier, was devastating for the then sitting Waterloo City Council. The report contained many conclusions and 31 recommendations. We will now look at some of the ethical issues given rise to by this case.

\section{The Elected Representative's "Duty of Care"}

At any level of government, unless by happenstance, it would be unreasonable to expect elected officials to have sophisticated corporate finance expertise; or, for that matter, expertise in enterprise system technology, urban planning, infrastructure construction or state owned and operated healthcare systems. For these are the domains of specialists. But since legislators must make decisions about these matters, is there not some acceptable level of care that they should be ethically duty-bound to exercise on behalf of the citizens of the country, province, state, city or town that they are governing? What, then, is a "duty of care" as it relates to public sector governance? 
It is common to find the obligations of elected officials and public servants to be set out in codes, by-laws, regulations or legislative acts. This is true whatever the political jurisdiction in question. In the case at hand, the Mayor and Councilors of the City of Waterloo are subject to the provisions of the Province of Ontario's Municipal Act. The Act requires each municipality in the Province to provide necessary and desirable services, manage and preserve public assets, foster the current and future economic, social and environmental well-being of the community and deliver and participate in provincial programs and initiatives (Municipal Act, Part 1, Sec. 2). It is performance obligations such as these that constitute what a public official must do in the public interest. Committing to discharge these obligations, whether by public oath or employment contract, is what establishes their duty of care.

What is the nature of this duty that is owed to citizens? Two aspects are useful to note. First, fulfilling such a duty requires that one be careful - act with care. Being careful is a state of mind, a way of thinking about things. It is the mindset of caution and prudence. No matter what the issue, we should be able to rely on our elected leaders to have our welfare top-of-mind. We want them to be judicious and forward thinking about the implications of their decisions. This is what being careful means. What this would entail in practical terms is being curious and wanting to know. And this should manifest itself in asking probing questions, challenging and sometimes confronting. It is using common sense, at the level as would be expected of a reasonable person.

The second aspect of a duty of care has to do with the process of exercising the duty. That is, for an elected representative to "take care", it is not enough simply to be cautious, prudent and judicious. He or she must do something that embodies this mindset. And that process is diligence. A careful person is diligent. Being diligent in public sector governance is to do due diligence. Elected representatives, as individuals, may not understand the intricacies of a tax-driven lease-and-lease-back financing transaction or other highly specialized matters. But theirs is not a duty of skill. They are not obligated to have experience, training and expertise in all matters over which they have jurisdiction. Theirs is the duty of a reasonable person. What they must do is to assure themselves that all necessary steps of the due diligence process have been taken; that all required expertise, both internal and external, has been brought to bear on the analysis of the issues at hand. In other words, the elected representative's due diligence is not that of a specialist. Rather, it entails an assessment of the adequacy of a due diligence process, and the assurance that it has been carried out.

In the RIM Park case, Justice Sills was highly critical of the elected City Council (Sills, pages 182-83). He certainly would not have attributed to them the mindset of caution, prudence and judiciousness. After all, Council passed the motion to accept the transaction as presented with virtually no questions being asked of the City Treasurer before, during or after his presentation at the Council meeting. And, as to due diligence, Sills was even more critical. He noted that this was the largest transaction in the City's history and the Council had relied entirely on the City staff, despite the fact that none of them had ever had experience with this sort of financing. He expressed dismay at the inadequate preparation of City staff. For instance, no attempt was made to expand the mandate of the City's external legal council to ensure his complete review of the transaction. Nor was the City's auditor asked to review the structure of the deal, including what they thought was a tax play. As Justice Sills commented about Council, "Part of their due diligence questioning should have involved pointed questions about the process used by staff to ensure that the transaction was valid" (Sills, page 183).

There are lessons to be learned from the RIM Park case that are applicable to elected representatives in all levels of government. Let us start by recognizing that elected governments have political ideologies and agendas. And these will impact decisions about policies and the way they are to be interpreted. However, despite the political orientation, governments make a commitment to citizens to perform specific duties of office, whatever those duties might be. A part of this commitment is a qualifier to performance. It is performance with care. What this entails is an attitude, approach, or perspective - a mindset that puts the interests of constituents first. Coupled with this is the diligence that they must exercise. Legislators must ensure that all reasonable measures have been taken to consult the appropriate expertise in assessing the opportunities and risks inherent in the decision to be made. They must be able to answer the question, is the process that has been followed likely to yield an accurate assessment of the facts, details and issues relevant and necessary to making a sound decision? If so, they have discharged their duty of care. 


\section{Procurement of Goods and Services and the Obligation to Issue Public Tenders}

In the RIM case, the senior City officials dealt only with one supplier of financing services rather than issuing a public tender. The Inquiry determined that this was in violation of the City's procurement policy. Clearly, this was an administrative process flaw, but does it have anything to do with ethics? Yes. It has to do with both protecting the public's interests by providing fair value for tax dollars and fairness to those participating in the procurement process as bidders.

When it comes to safeguarding the public's interests by ensuring fair value in procuring goods or services, three considerations are important. The first has to do with quality (or, by implication the qualifications of service providers, to deliver quality). Whether in procuring the services of a public accounting firm to conduct the annual audit, or purchasing cement for a public infrastructure project, the goods or services must be of acceptable quality to ensure that the public's resources are being deployed in their best interests. Second is economic value. The public's interests are served when procurements are made at the least expensive way. So, if a city was contracting for waste disposal services, it should normally go with the lowest bid consistent with an acceptable level of quality.

The third point mediates between the first two. It is appropriateness. Contrast two situations. Think of procuring some raw material for a construction project, such as bricks for the exterior walls of a hospital. Once the specifications of size and color have been determined, bids for the contract to supply these materials would be evaluated on the basis of quality and value. But suppose that in the process of procuring the services of an architect to design the hospital, the request for proposals contained an open invitation to architects to propose design solutions to the broad functional requirements of the hospital. As a result, the bidding firms might come up with very different designs and structural ways of dealing with what they understand the needs of the medical practitioners to be. So, when evaluating the proposals, it would not be sufficient merely to apply the principals of quality and value. A further level of judgment would be required to determine which design best meets the functional needs of the hospital, as well as esthetic, environmental and other considerations. These other decision making considerations I am bringing together under the heading of "appropriateness". And, this is usually called into action when the procurement in question is open-ended as regards the specifications of the good or service to be provided.

The other main ethical consideration deals with the process used in procurement and with ensuring that all participants are treated fairly. As I have argued elsewhere (A. Scott Carson, 2002), the procurement process should meet three tests of fairness: (1) accessibility, (2) transparency and (3) impartiality. The first component, accessibility, deals with the openness of the process to as wide a range of potential bidders as possible, thus allowing all interested qualified companies within the political jurisdiction an opportunity to bid. This protects against an unfair exclusivity that arises when a government opts to deal only with its political friends. (As an aside, there is a further issue that arises when considering the extent of accessibility of the request for bids. It could be argued that bids should be accepted only from companies within a limited political jurisdiction. This is a difficult issue that would take more space to discuss than we have available. So, it will be left for now as an open issue.)

Transparency in the process is the next element in process fairness. It involves ensuring that all participants understand precisely what is being asked of them and how their bids will be evaluated. Some processes can be quite opaque and leave bidders feeling that they have been unfairly dealt with because there may have been some requirements of the bid presentation or the way it was evaluated that, had they known about them, their bid could have been improved. In other words, they were not judged based on the basis of their true ability.

Finally, there is the importance of impartiality in making the selection of the winning bid. A bidder would not be treated fairly if its proposal was superior in terms of quality, price and appropriateness but was not selected because of political preferences by those in government making the final decision. The decision, if it is to be fair, must be made on the basis of the stated criteria and not some form of bias.

So, taking together both sets of principles - of fair value to the public and process fairness - we can relate them to the RIM Park financing and situations that other governments face in procurement. Justice Sills in the Inquiry found fault with the City's decision not to tender and attributed the disastrous result of the financing largely 
to this (Sills, pages 185-86). This raises an interesting ethical question that has broad application in municipal governance. Simply stated, should municipal governments procure goods and services by way of tender in each and every case without exception in order to ensure fairness in the public interest and to be fair to all potential providers of those goods or services? I think the answer is, usually, but there are justifiable exceptions. The reason is contained in the application of the appropriateness principle outlined above.

Procurement by public tender has the ethical seal of approval in most cases. But in some situations there should be exceptions, precisely to ensure that the public's interests are being served and to be fair to the provider of the good or service. Ironically perhaps, RIM Park might legitimately have been one of them had certain aspects of MFP's behavior been different.

Above we said that "appropriateness" can in some cases act as a mediator between "quality" and "value" when procuring goods or services in which the bids are qualitatively different from each other. The RIM Park financing concept as originally presented to the City of Waterloo had significant qualitative differences from conventional debenture financing. It had a variable lease payment schedule and length of term that could have provided significant benefits that would not have been available through conventional municipal financing methods. Equally, the promised effective interest rate, had it been real, would have been exceptional; well below anything available in the debt markets for municipal bonds. When the issue of tendering came up in discussion with MFP, the company's response was that it would withdraw the offer if it had to submit to a tender process.

MFP might have had a legitimate point, as could others in a similar situation. Leave aside for the moment both the unethical way in which the company dealt with Waterloo, and the fact that the financing product was not what was ultimately delivered. Suppose they genuinely had the ability to provide the tax driven benefits of the lease-and-lease-back financing. As a matter of fairness, why should MFP in that circumstance create an innovative financing product, give that proprietary knowledge to competitors, then bid against those other market participants on the basis of lowest price? Potentially, they could lose the bid to another company who, with the benefit of MFP's proprietary knowledge, undercut them in price. Is there not an argument for innovative suppliers being given an opportunity to satisfy a government that its product will meet all of its needs for quality, value and appropriateness, and in return be allowed to supply the product without further market competition?

There is a real risk to governments, if they are not prepared to consider the prospect of working with a sole provider of a good or service. If the provider is bringing a genuine innovation, the government would not be able to make it available to the public and potentially deprive it of obtaining fair value. In the process, legislators could be acting unfairly to the provider.

In the RIM case, the claims about low interest rates and a tax-structured lease were clearly bogus. And, based on the evidence heard in the Inquiry, MFP's conduct in dealing with City staff was unethical. But, the bulk of the misunderstandings, errors and omissions of relevant facts would have been apparent had the staff done adequate due diligence. Justice Sills says this forcefully (Sills, pages 185-86). But he goes on to draw an unwarranted conclusion. That is, he recommends that henceforth all financing arrangements should be tendered (Sills, page 187). I do not think that he, or we, should conclude this. If we agree that a thorough due diligence, as part of the duty of care, is always essential, it is not necessary to mandate tendering.

To conclude, the ethical imperatives in protecting the public's interest are quality, cost and appropriateness. However, an innovative product or service procurement could potentially deliver each of these, even if there is no tendering. The public's protection is in the quality of the due diligence. Conversely, if tendering is always mandated, governments cut themselves off from highly innovative goods and services and sacrifice the public good in the process. Tendering is a key element in public sector procurement. But it is only a means, not an end, to the achievement of fair value and process fairness. 


\section{Conflict of Interest Standards for Public Sector Employees and the "Height of the Bar"}

The issue to be addressed is not whether government officials, elected or employed, should be required to adhere to policies on conflict of interest. Of course they should. But is there a case to be made for holding public sector officials to a higher standard than would normally be the case in the private sector?

Conflicts of interest normally arise when we are faced with either one of two situations. The first occurs when we have two competing obligations or duties. For instance, a lawyer who represented two clients that were in a legal dispute with each other would be in a conflict situation. The lawyer could not fulfill his or her obligation to one client without interfering with the obligation to the other one.

The second situation occurs when we have personal interests, or something to gain, at the expense of our obligation or duty to another person, employer, organization, etc. For instance, the conflict of interest policy in force at the time of the RIM Park scandal in part read as follows: "A conflict of interest is defined as a conflict between an employee's personal interest and his/her responsibility as an employee of the City of Waterloo that interferes with or has the potential to interfere with the performance of his/her position in serving the interests of the City of Waterloo" (Sills, page 163).

The City of Waterloo policy makes a distinction between conflicts and "potential" conflicts. But, some ethicists also contend that it is not only "actual" or "potential" conflicts, but also the appearance of conflicts that are important. In other words, beyond what does, or may, happen; it is what people think might, or did, happen is key. Justice Sills also takes this view when he says in the Inquiry Report, "A conflict of interest may create doubts or suspicions concerning the integrity or fairness of decisions made. The appearance of a conflict may in some cases, be as damaging as a real conflict" (Sills, page 163). Similarly, the Government of Canada's values and ethics code for all federal government public servants states: "Avoiding and preventing situations that could give rise to a conflict of interest, or the appearance of a conflict of interest, is one of the primary means by which a public servant maintains public confidence in the impartiality and objectivity of the Public Service" (Values and Ethics Code for the Public Service, Chapter 2).

In municipal and other levels of government, both types of conflict of interest can occur. For our purposes, though, most relevant is the second type. So, we will focus on conflicts involving the juxtaposition of personal interests and obligations to the government. Let us then look more closely at what we mean by "personal interests" and "obligations" in the RIM Park and other similar cases.

Regulation 435/97 of the Ontario Public Service Act (Sills, page 164) stipulates in, 5(1), that "A public servant shall not accept a gift ...if a reasonable person might conclude that the gift could influence the public servant when performing his or her duties to the Crown". The regulation goes on to list those from whom the prohibited gifts might come. The next subsection, 5(2) qualifies the one before saying that it "shall not operate to prevent a public servant from accepting a gift of nominal value given as an expression of courtesy or hospitality if doing so is reasonable in the circumstances". Both points are compatible with the Canadian Federal Government guidelines (Values and Ethics Code for the Public Service, Chapter 2).

So, bringing together the guidelines of each of the City of Waterloo, Province of Ontario and Government of Canada, the focus is on the extent to which the gift or hospitality might "influence" the decision making or behavior of the public servant in discharging his or her duties to the government. And, how are we to decide the extent of actual, potential or perceived influence? We are told by the Ontario policy to use the "reasonable person" or "reasonable in the circumstances" tests. Our question now becomes, what is reasonable, and to whom?

Consider what the issue involving "influence" was in the RIM Park case. It was brought out in the Inquiry that the Chief Administrative Officer of the City of Waterloo, both before and after the leasing transaction was signed, had been MFP's guest at two company client appreciation day golf tournaments, a Millennium celebration, two charity functions, dinner and cocktails at a fireworks show, a regional festival, a Maple Leafs hockey game and 
a paid golf trip to Florida. To a much lesser extent, other public servants and the then Mayor attended hospitality events. All of this took place between autumn 1999 and spring 2001.

MFP's rationale for this entertainment was business development and client relationship management. The CAO's explanation of his conduct was that he had been directed by the City Council to develop business relations with individuals and organizations that could be business partners with the City (Sills, page 166). As Justice Sills indicated, "The system of governance in Waterloo not only permitted but also encouraged 'schmoozing' with suppliers by senior staff' (Sills, page 169).

In drawing his conclusions, Justice Sills sidestepped the issue of what influence this might actually have had on the CAO's judgments and instead found fault with both the COA's failure to disclose these benefits, and the looseness of the City's conflict of interest guidelines. However, the question of influence pervaded the public's perception throughout the entire incident. In the public's view, the CAO had not met the "reasonable person" or "reasonable in the circumstances" tests. What, then, would have been reasonable?

Two things are important to consider here. First is the extent of scrutiny by the public of government entities in a democracy. The media, interest groups, political opposition parties, changing public opinions and priorities and the need to face the electorate in elections, cause politicians and public servants to be viewed and evaluated on a continuing basis. Indeed governments at all levels accommodate themselves to this by encouraging openness and visibility through a variety of public forums for consultation and disclosure on a wide range of issues. So, to a much greater extent than for private sector enterprises, governments are held visibly and publicly to account for their actions. As a result, even perceived conflicts of interest are readily detected under the public microscope.

A second feature contributes to the heightened scrutiny as well. There can be a large discrepancy in socioeconomic status between the lowest and highest in any given political jurisdiction. For instance, the State Senate of New York must legislate for the poor and low-income earners in the Bronx as well as the Upper East Side Manhattan economic elites - and citizens from all of the gradations of income and social positioning in between. So, when it comes to perceptions about the influence that hospitality benefits might have on a New York State public servant's decision on some matter, it depends very much on who is doing the perceiving. An expensive dinner followed by a Rangers hockey game is not all out of keeping with normal business entertainment by corporate executives on Wall Street. And given the high socio-economic status of those partaking of this, rarely would such hospitality be seen as anything more than a normal corporate relationship building business practice. But, to an hourly paid laborer in the non-affluent Bronx, this could seem luxurious. Such a person witnessing public servants from Albany being entertained by an investment banker or leasing company executive in this way could certainly be forgiven for perceiving this as influence buying, or at very least a clear imbalance between public duty and personal benefits. Consequently, when applying the reasonable person, or reasonable in the circumstances test, the evaluation of reasonableness will very much depend upon to whom the question is being addressed.

At this juncture one might protest that public servants of good character who act with integrity are no more prone to selling political favors for dinners and hockey games than well off corporate executives. Nothing said here should be taken to dispute this. So, it is important to be clear about why the height of the conflict of interest bar is even in question.

The point is not that public officials are more susceptible to actual or potential conflicts of interest. It is the appearance of conflict that is the issue. Because those who work in the public sector are so publicly visible, and because they are evaluated by citizens of such widely ranging backgrounds and life-experiences, it seems reasonable to conclude that they will be held more tightly to account than would their private sector counterparts whose accountabilities and disclosures are more limited. And, given the public servant's commitment to serve the citizens, whether because he or she holds elected office, or provides administrative support to those who do, it seems reasonable to conclude that, as a matter of prudence, a higher bar should be set when developing and implementing conflict of interest policies. 
Whether the CAO and others in the Waterloo City government were in fact influenced by the corporate largesse or not is beside the point. It was suspected in the public domain that they were. What would quite likely have been acceptable in the corporate world that MFP inhabited, was not acceptable to many of the citizens of Waterloo. What is instructive about the RIM Park case is the broad applicability of its lesson. Few government employees in a democracy can expect to be far from the glare of public scrutiny over conflicts between personal benefit and public duty. While they might at times envy their private sector counterparts, the different reality of their professional lives must be recognized and accepted.

\section{Good Corporate Citizenship When Working with Governments}

Corporate citizenship is a slightly more focused version of a broad theme known as corporate social responsibility (CSR). The literature on CSR has grown massively over the past two decades. The basic tenant is "the voluntary assumption of responsibilities that go beyond the purely economic and legal responsibilities of business firms. More specifically, social responsibility according to some accounts, is the selection of corporate goals and the evaluation of outcomes not solely by the criteria of profitability and organizational well-being but by ethical standards or judgments of social desirability" (John R. Boatright, page 373). The sort of things that typically are said to illustrate a socially responsible corporation, i.e., good corporate citizen, would be making contributions to charities and community oriented organizations, and actively seeking out ways of bettering the community (and society as a whole) such as by adopting stringent environmental protection, product safety and employee safety standards.

There is a longstanding debate about whether corporations have social obligations. The classical view against CSR, most forcefully represented by the Nobel Prize winning economist Milton Friedman, is that over and above certain basic laws limiting corporate freedoms to enable the marketplace to function, the fundamental role of the corporation is to use its resources to make a profit. "so long as it engages in free enterprise and open competition with out deception or fraud" (Milton Friedman, 1962, page 133). Supporting social programs is not the role of a corporation. For management to give corporate funds to charities, for instance, is simply to take money out of the pockets of shareholders. It is essentially a form of taxation. Donations to charities, social programs, etc. should come from shareholders as individual donors and governments through taxation, not from the corporation itself (Friedman, 1970, page 33).

Arguments in favor of CSR at a minimum level contend that business activity in a free market depends at very least on such ethical behaviors as honesty, truth and dependability in honoring contracts (Theodore Levitt, page 49). Other arguments push this further and look at the changing role of corporations in society. The contention is that because corporations have grown so large and powerful, they play a very different role in society than previously was the case. Their massive size and resource base brings with it a special obligation to promote social goals in addition to economics advantages for shareholders. Essentially, the argument is that because they can advance social goals, they should (Keith Davis, page 20; William C. Fredrick; Donna J. Wood).

We do not have space here to evaluate the cogency of these longstanding arguments and settle the debate. So, it is proposed that for present purposes we accept what is arguably the prevailing business view today, that corporations have a least some level of social responsibility. On this basis, we will see how the CSR position relates to the role played by Clarica in purchasing the lease from MFP and its subsequent dealing with the City of Waterloo, in order to draw wider governance implications.

In the RIM Park financing, MFP led the City of Waterloo to believe that it would be receiving a belowmarket interest rate because of a specialized tax structure. This was not true, and Clarica knew this. What were Clarica's ethical obligations as a good corporate citizen, if any?

To start, Justice Sills did not find that Clarica acted in any way outside of its legal obligations. He did think, however, that the company was ethically bound to ensure that the City actually understood the deal when there was so much evidence to suggest that the City did not. Clarica tried to show the Inquiry that it had acted properly by asserting that, as a third party, it had no obligation other than that of confidentiality to MFP. And, when 
it finally became fully aware of the City's misunderstanding upon seeing the draft press release, the company moved swiftly to meet with the City.

Justice Sills did not accept Clarica's claim of third party status. He pointed to the close proximity in time of closing the lease transaction and its assignment to Clarica, the fact that Clarica's legal counsel had taken part in drafting the lease documentation and the insistence by Clarica's legal counsel that the City's lawyer addressed his opinion letter to Clarica not MFP. To Justice Sills, this was all one transaction and the most fundamental relationship existed between the City who borrowed the money and Clarica who was the lender. In the eyes of the Inquiry, the City's lack of knowledge of sophisticated financing structures put it at such a disadvantage that it was not a fair transaction between willing parties. Because there were so many red flags, given the local publicity of the sub-market rate in the media and the knowledge Clarica had of the above market pricing of the actual deal, Clarica should have known that it was dealing with an unsophisticated party and therefore had an ethical obligation to draw the true nature of the deal to the City before it closed. This was made all the more pressing given the prominent role that Clarica and its senior executives played in the community. What, then, does this tell us about the ethical relationship between governments and private sector corporations when doing business together?

Let us ask two general questions that might help us to understand the broader issues at stake. First, when any two parties enter into a transaction, notwithstanding who they are, are there any circumstances under which one party has a moral obligation to inform the other that it is misunderstanding or failing to understand something essential to pursuing or safeguarding its own interests? I suggest that the answer is yes in cases of fraudulent misrepresentation, or where one party was prevented from having access to information necessary to establishing what is in its interests. It is important to note here that the issue is not whether one party might have had significantly more knowledge than the other. Rather, it is that one party could not have known, or was prevented from knowing, what it needed to know to protect its interests. In the general case, I think it would be uncontroversial to say that based on the premise that ethical dealings must be fair, these two instances would be seen to be ethically problematic.

One may conjecture that Clarica knew, or should have known, much earlier than it did, that the City was subject to misrepresentations, but that is not our question. We want to know whether a company in Clarica's situation should come to the aid specifically of a public sector entity, not because of a fraudulent or forced knowledge imbalance, but because of something particularly to do with good corporate citizenship.

Two ways this might be argued are as follows. First, it might be claimed that in sophisticated financial transactions, governments will necessarily be over their heads when dealing with the private sector. This would be very difficult to demonstrate given the amount of procurement that governments currently do with the private sector. We would need to evaluate specific situations which would note be feasible. But, for the sake of argument, let us say in that in some particular situation this is so, that there is a knowledge imbalance. If the public sector party could have access to expertise that would enable the imbalance to be addressed, then it seems that the fair dealing principle has not been breached, even if the public sector entity chose not to consult the available experts. It would be different if the public sector entity was so unsophisticated that it simply did not know what knowledge it was lacking, and had no reasonable way of finding out. In this case, on the face of it, there would be a moral obligation. But a knowledge imbalance in and of itself does not constitute an unfair deal. For example, an art dealer who takes advantage of a neophyte who could have brought someone of expertise with him or her but chose not to do so, is not guilty of any moral infraction. Hence, the good corporate citizen argument does not work if it is based on the presumption of governments having an inherent disadvantage, even if it is understood that the needed expertise may need to come from external consultations.

The second argument is that obligations of good corporate citizenship flow from membership in a community. This is a very difficult issue to deal with in a short space. There is an extensive body of literature that analyzes the concept of community and the extent to which corporations can be said to be part of various communities. The general difficulty in grasping the essential nature of community membership is the ever-widening circle of what could be identified as the business community, global business community, and so on. So, I propose to stay with the more manageable situation exemplified by the City of Waterloo and Clarica. For, in this illustrative 
case, we have a large national corporation that is a longstanding resident of the City, is one of the area's largest employers, and is involved in many social and charitable projects. Why this is helpful is that it is possible to describe Clarica, or any company in similar circumstances, as in some sense being a part of the community without having to defend the idea of membership in communities that are conceptually or physically very large and remote from the actual community members who comprise the alleged community.

So, what about the general situation of a large company in a small or mid sized city? Is there a special obligation of corporate citizenship? In this restricted case, the answer is a qualified yes. The rationale stems from the traditional notions of belonging to a community and believing in the importance of giving back to the community in which the company's employees live, work, enjoy public amenities, and share social interactions. (To some extent, this is compatible with some feminist ethics positions that promote ethical conduct on the basis of values caring relationships.) However, the moral standing of the company is not necessarily one of obligation in the strict sense. For an obligation requires compliance. If one repudiates or does not discharge a moral obligation, one is morally blameworthy. I do not think this would be so in the case we are considering. It is difficult to see why a corporation must, morally, proactively determine whether a government with whom it is doing business clearly knows all of the facts relevant to advancing its own interests. This seems to go beyond a reasonable level of community commitment.

What does seem reasonable, though, is a variation of what is sometimes knows as the "Good Samaritan Principle". Simply stated, the company may not be morally blameworthy for not looking out for the interests of its municipal counterpart, but it would be morally praiseworthy if it did. This is a softer form of moral agency that works off voluntary commitment rather than required conduct. In a sense, it captures something at the core of moral behavior, namely the intent to do the ethical thing. Archie Carroll refers to this as "Discretionary/philanthropic responsibility" (Archie Carroll, page 142-43). It is the acceptance by a company of a moral responsibility that it would not necessarily insist that other companies must likewise do. We would find it commendable if other companies accepted this responsibility. But we would not go so far as to condemn them if they did not.

What then would this suggest for municipal governance in general? Of the ethical issues we have discussed, this is the most difficult in terms of suggested guidelines or rules. While we can say that in situations where two or more parties are entering into a transaction, and it is clear that one of them is being mislead, misinformed or prevented from access to required information, it is the ethical obligation of the others to draw this to their attention. This is applicable whether governments are involved or not. But, does good corporate citizenship in dealing with governments require proactive steps to help? That is going too far.

\section{Concluding Note}

The RIM Park financing scandal continues to generate news in Waterloo, but this will eventually settle. Hopefully, though, it holds useful lessons for public sector governance in general. Issues concerning the duty of care apply as much to the private as public sector. It is difficult to pick up a newspaper today without seeking new corporate scandals and a trail back to the boardroom where directors were not discharging their most basic obligations. Procurement, and issues around tendering, will increase as public-private-partnerships continue to expand. Public infrastructure in most countries simply requires private capital, so the way governments and business deal with each other will become ever more pressing. As this grows, so will issues around conflict of interest. Partners in both the public and private sectors will need to clarify their guidelines and work hard to manage them. Finally, the business dealings between the public and private sectors will require both to make an effort to understand each other's needs. As to two sectors become closer as business partners, ethical dealings between them will increase in importance. Both will need to be good organizational citizens. 


\section{References}

1. Boatright, John R. 2003. Ethics and the Conduct of Business. Prentice-Hall, Upper Saddle River NJ.

2. Carroll, Archie, 1998. "Shareholder thinking in three models of management morality: A perspective with strategic implications". In Max B. E. Clarkson, ed. The Corporation and Its Stakeholders: Classic and Contemporary Readings. University of Toronto Press, Toronto ON, pp. 139-70.

3. Davis, Keith. 1975. Five propositions for social responsibility, Business Horizons, 18, June (cited in Boatright).

4. Carson, A. Scott. 2002. Establishing public-private partnerships: Three tests of a good process. Proceedings of the International Applied Business Research Conference, Puerto Vallarta, Mexico, March 14-19, 2002. Republished by the Canadian Council for Public-Private Partnerships, Website: www.pppcouncil.ca/voices/htm, January 2003.

5. Fredrick, William C. 1994. "From CSR1 to CSR2: the maturing of business-and-society thought", Business \& Society Review, 33, pp. 150-64.

6. $\quad$ Friedman, Milton. 1962. Capitalism and Freedom. University of Chicago Press, Chicago.

7. Friedman, Milton. 1970. "The social responsibility of business in to increase its profits", New York Times Magazine, September 13.

8. Government of Canada. Values and Ethics Code for the Public Service. Treasury Board of Canada Secretariat.

9. Government of Ontario. 2003. Municipal Act.

10. Levitt, Theodore. 1958. The dangers of social responsibility, Harvard Business Review, SeptemberOctober.

11. Sills, Hon. Ronald C. Sills. 2003. Report of the Waterloo RIM Park Inquiry. Waterloo ON.

12. The Record

13. May 19, 2001, page A01.

14. June 1, 2001, page A01

15. June 4, 2001, page A01

16. June 20, 2001, page A01

17. June 30, 2001, page B01

18. July 25, 2001, page A01

19. Wood, Donna J. 1991. "Corporate social performance revisited", Academy of Management Review, 16 (cited in Boatright). 
Notes 